\title{
Odontogenic tumors: a 14-year retrospective study in Santa Catarina, Brazil
}

\section{Grasieli de Oliveira Ramos ${ }^{(a)}$ Juliana Cristina Porto ${ }^{(b)}$ Daniella Serafim Couto Vieira ${ }^{(c)}$ Filipe Modolo Siqueira (c) Elena Riet Correa Rivero(c)}

(a) Graduate Program in Dentistry, Health Sciences Center, Universidade Federal de Santa Catarina - UFSC, Florianópolis, SC, Brazil.

(b) Undergraduate Course in Dentistry, Health Sciences Center, Universidade Federal de Santa Catarina - UFSC, Florianópolis, SC, Brazil.

(c) Department of Pathology, Health Sciences Center, Universidade Federal de Santa Catarina - UFSC, Florianópolis, SC, Brazil.

Declaration of Interests: The authors certify that they have no commercial or associative interest that represents a conflict of interest in connection with the manuscript.

Corresponding Author:

Elena Riet Correa Rivero

E-mail: riet@ccs.ufsc.br

http://dx.doi.org/10.1590/S1806-83242013005000030 Epub Nov 09, 2013

Submitted: May 06, 2013

Accepted for publication: Sep 30, 2013

Last revision: Oct 06, 2013
Abstract: Odontogenic tumors (OTs) are lesions that develop exclusively on maxillary bones, and form a heterogeneous group. They vary from hamartomatous lesions to benign and malign tumors. Although they are rarely observed in dentistry clinics, it is extremely important for the dentist to be aware of them. The aim of this study was to investigate the incidence of odontogenic tumors diagnosed in the population of Florianópolis, Santa Catarina, Brazil. Cases of odontogenic tumors were selected from the anatomopathological diagnostic services at Federal University of Santa Catarina from 1998 to 2011. Clinical data on these cases were collected from biopsy reports and patient files. Seventy-eight cases of odontogenic tumors were surveyed. Of these diagnoses, 51\% were keratocystic odontogenic tumors (KCOTs); the remaining cases were mainly ameloblastomas and odontomas. The most frequently observed lesion in this retrospective study was KCOT (more than half of cases). Thus, this study shows that modifying the classification of the OTs altered the frequency of the lesions, possibly making KCOT the most common lesion observed in diagnostic services worldwide.

Descriptors: Odontogenic Tumors; Pathology, Oral; Epidemiology.

\section{Introduction}

Odontogenic tumors (OTs) develop exclusively on gnathic bones through the proliferation of odontogenic tissues (epithelial, mesenchymal or both). They form a heterogeneous group of hamartomatous lesions, benign and malign tumors. According to their origins, they are divided into epithelial, ectomesenchymal, and mesenchymal. Among the most frequent OTs are keratocystic odontogenic tumors (KCOTs), ameloblastomas, and odontomas. ${ }^{1}$

Over time, OTs have passed through several modifications in their classification. In 1869, Broca used the term "odontoma" for any lesion arising from tissues that were part of the dental formation. ${ }^{2}$ Later, several authors began to use and modify this terminology, and it was only in 1971 that the World Health Organization (WHO) published the first guide for the classification of OTs. ${ }^{3}$ In the most recent classification, "WHO Classification of Tumors - Head and Neck Tumours" in 2005, there were several modifications. One was the inclusion of the keratocystic odontogenic tumor in the category of benign tumors; it was no longer categorized as an odontogenic cyst. ${ }^{2}$ Information was also added 
concerning lesions, including their definition, epidemiology, etiology, clinical and imaging features, and genetics. $^{4}$

OTs are rare lesions in dentistry clinics, and their incidence varies based on geographic location. In Brazil, studies report that the incidence of these lesions varies between $2.4 \%,{ }^{5}$ and $6.8 \%$ of all diagnosed oral lesions. Findings from other parts of Latin America are similar, such as those by Ledesma-Montes et al., ${ }^{7}$ whose multicentric study (realized in Mexico and Guatemala) observed a $2.16 \%$ incidence of OTs, and in another study performed in Chile in which the authors found an incidence of $1.29 \%$ for $\mathrm{OTs}^{8}$ among all the oral lesions diagnosed in their services. Studies from other parts of the world, such as the one conducted by Jones and Franklin ${ }^{9}$ in the United Kingdom, found a lower frequency of $0.8 \%$ for all OTs. However, reports from Nigeria showed a greater prevalence of OTs, such as frequencies of $9.6 \%$ and $19 \%$ observed in studies by Ladeinde et al. ${ }^{10}$ and Odukoya, ${ }^{11}$ respectively.

The aim of the present study was to investigate the incidence and main characteristics of OT cases that were diagnosed at the Universidade Federal de Santa Catarina in two diagnostic services, which are references to the Santa Catarina State.

\section{Methodology}

Cases for the study were selected from histopathological reports of two diagnostic services of the Universidade Federal de Santa Catarina - UFSC, the Oral Pathology Laboratory and the Pathological Anatomy Service, from 2006 to 2011 and from 1998 to 2010, respectively. Slides stained with hematoxylin and eosin (H\&E) were selected from the histopathological diagnosis reports for evaluation under light microscopy (Olympus Corporation, Tokyo, Japan) and classified according to WHO criteria. ${ }^{1}$ Clinical data were collected from biopsy reports stored by both services, as well as from the hospital records. Patient information included gender, age, ethnic group and, in KCOT cases, association with nevoid basal cell carcinoma syndrome (NBCCS), also known as Gorlin syndrome. Lesion-related data were the location, clinical and radiographic aspects of the lesions. Data were collected and, af-
Table 1 - Distribution of the cases diagnosed.

\begin{tabular}{l|c|c}
\hline Diagnoses & $\mathrm{n}$ & $\%$ \\
\hline Keratocystic odontogenic tumor & 40 & 51 \\
\hline Ameloblastoma & 18 & 23 \\
\hline Odontoma & 13 & 17 \\
\hline Odontogenic myxoma & 2 & 3 \\
\hline Calcifying cystic odontogenic tumor & 2 & 3 \\
\hline Cementoblastoma & 1 & 1 \\
\hline Central odontogenic fibroma & 1 & 1 \\
\hline Calcifying epithelial odontogenic tumor & 1 & 1 \\
\hline Total & 78 & 100 \\
\hline
\end{tabular}

Table 2 - Cases diagnosed distributed by gender.

\begin{tabular}{l|c|c|c|c}
\hline \multirow{2}{*}{ Diagnoses } & \multicolumn{2}{|c|}{ Male } & \multicolumn{2}{c}{ Female } \\
\cline { 2 - 5 } & $\mathrm{n}$ & $\%$ & $\mathrm{n}$ & $\%$ \\
\hline Keratocystic odontogenic tumor & 15 & 62 & 10 & 38 \\
\hline Ameloblastoma & 9 & 50 & 9 & 50 \\
\hline Odontoma & 6 & 46 & 7 & 54 \\
\hline Odontogenic myxoma & 1 & 50 & 1 & 50 \\
\hline Calcifying cystic odontogenic tumor & - & - & 2 & 100 \\
\hline Cementoblastoma & - & - & 1 & 100 \\
\hline Central odontogenic fibroma & 1 & 100 & - & - \\
\hline Calcifying epithelial odontogenic tumor & - & - & 1 & 100 \\
\hline Total & 32 & 51 & 31 & 49 \\
\hline
\end{tabular}

ter being filed in an initial format, they were later filed in a Microsoft Excel $^{\circledR}$ (Microsoft Corporation, Redmond, USA) spreadsheet. Descriptive statistical analysis was performed with all collected data using Microsoft Excel ${ }^{\circledR}$ software. This study was approved by the Ethics Committee for Research with Human Beings at UFSC under number 1055/10.

\section{Results}

In our study, OTs corresponded to $3 \%$ of all oral lesions diagnosed by both services. In Table 1, we can observe the general prevalence of the lesions in these cases. These cases occurred more frequently in male patients (Table 2) and Caucasian (89\%). The lesions were most prevalent in the age group between 21 and 30 years (Table 3). The preferential location was the posterior region of the mandible 
Table 3 - Distribution according to the patients' age group.

\begin{tabular}{|c|c|c|c|c|c|c|c|c|c|c|}
\hline \multirow{2}{*}{ Diagnoses } & \multirow{2}{*}{$\begin{array}{l}\text { Age } \\
\text { group }\end{array}$} & \multirow{2}{*}{$\begin{array}{c}\text { Mean } \\
\text { age }\end{array}$} & \multicolumn{8}{|c|}{ Age Group } \\
\hline & & & $00-10$ & $11-20$ & $21-30$ & $31-40$ & $41-50$ & $51-60$ & $61-70$ & $71-80$ \\
\hline Keratocystic odontogenic tumor & $05-71$ & 35.5 & 1 & 5 & 7 & 3 & 3 & 3 & 2 & 1 \\
\hline Ameloblastoma & $15-64$ & 27.25 & - & 4 & 10 & 2 & 1 & - & 1 & - \\
\hline Odontoma & $06-75$ & 25 & 4 & 2 & 3 & - & 1 & 1 & - & 1 \\
\hline Odontogenic myxoma & $08-32$ & 20 & 1 & - & - & 1 & - & - & - & - \\
\hline Calcifying cystic odontogenic tumor & $12-70$ & 41 & - & 1 & - & - & - & - & 1 & - \\
\hline Cementoblastoma & 37 & 37 & - & - & - & 1 & - & - & - & - \\
\hline Central odontogenic fibroma & 18 & 18 & - & 1 & - & - & - & - & - & - \\
\hline Calcifying epithelial odontogenic tumor & 31 & 31 & - & - & - & 1 & - & - & - & - \\
\hline Total & $05-75$ & 30.36 & 6 & 13 & 20 & 8 & 5 & 4 & 4 & 2 \\
\hline
\end{tabular}

Table 4 - Distribution of the cases according to the predominant location of the lesion.

\begin{tabular}{l|c|c|c|c|c|c}
\hline Diagnoses & $\begin{array}{c}\text { Posterior } \\
\text { mandible }\end{array}$ & $\begin{array}{c}\text { Anterior } \\
\text { mandible }\end{array}$ & $\begin{array}{c}\text { Posterior } \\
\text { maxilla }\end{array}$ & $\begin{array}{c}\text { Anterior } \\
\text { maxilla }\end{array}$ & Other & $\mathrm{n}$ \\
\hline Keratocystic odontogenic tumor & 22 & 8 & 5 & 2 & 3 & 40 \\
\hline Ameloblastoma & 15 & 1 & - & - & 2 & 18 \\
\hline Odontoma & 4 & 3 & 2 & 3 & - & 12 \\
\hline Odontogenic myxoma & 2 & - & - & 1 & - & 3 \\
\hline Calcifying cystic odontogenic tumor & - & - & - & 2 & - & 2 \\
\hline Cementoblastoma & 1 & - & - & - & - & 1 \\
\hline Central odontogenic fibroma & 1 & - & - & - & - & 1 \\
\hline Calcifying epithelial odontogenic tumor & 1 & - & - & - & - & 1 \\
\hline Total & 46 & 12 & 7 & 8 & 5 & 78 \\
\hline
\end{tabular}

(Table 4), and the lesions presented as radiolucent images $(74 \%)$, mixed radiolucent-radiopaque $(10 \%)$ or radiopaque $(4 \%)$. Among radiolucent lesions, the largest number of lesions was KCOT (64\%), followed by ameloblastoma (34\%) and myxoma (2\%). Among mixed lesions, 57\% were odontomas, followed by a calcifying cystic odontogenic tumor (CCOT, 28\%) and a calcifying epithelial odontogenic tumor (CEOT, 15\%). Among the radiopaque lesions two cases were odontomas (67\%), and one case was cementoblastoma (33\%). Nine cases (12\%) had no information concerning radiographic characteristics: seven were odontoma (78\%), one case was myxoma (11\%), and one case was central odontogenic fibroma (COF, $11 \%$ ).

KCOT was the most prevalent lesion in our study, with $51 \%$ of the cases diagnosed in both ser- vices, and it occurred more frequently in male patients with a mean age of 35 years, varying between 5 and 75 years. These KCOT cases occurred in all areas of the maxillary bones, although the most frequent were the posterior mandible. Of all KCOT cases diagnosed in both services, $40 \%$ were associated with NBCCS. When we evaluated the KCOT cases associated with NBCCS, and the isolated KCOT cases, we verified that the mean age of the cases associated with the syndrome was 28 years, whereas the mean age for patients without the syndrome was 31 years. The ethnic group, and gender distributions were very similar between the two groups (KCOT cases associated with NBCCS, and isolated KCOT cases). We also checked the number of recurrence, and found seven cases of recurrence, of which two were associated with NBCCS. Occurrence of mul- 
tiple lesions, all associated with the syndrome, was observed in four patients.

The second-most frequent lesion, ameloblastoma, did not show prevalence based on gender and the mean age of the patients was 27 years, varying between 15 and 64 years. All cases of ameloblastoma occurred in the mandible, mainly in the posterior area. Ameloblastoma occurred in two different clinical presentations, solid $(61 \%)$ and unicystic (39\%). All cases were histologically classified, being divided into follicular (33\%), plexiform (22\%), association between plexiform and follicular (96\%), unicystic with mural proliferation $(22 \%)$, unicystic with luminal proliferation (11\%), and unicystic with intraluminal proliferation $(6 \%)$.

The third-most prevalent lesion, odontoma, showed a slight preponderance for the female gender, and most of the cases occurred in young patients up to 10 years of age. The preferential location for this lesion was the posterior mandibular area.

\section{Discussion}

OTs are lesions rarely observed in dentistry clinics, ${ }^{5-7,9,12,13}$ and their frequency was $3 \%$ in our study, with a mean age of 30 years, varying between 5 and 75 years, and occurring more often in male patients. Their main location was in the posterior mandibular area. These data agree with findings from other studies performed in different countries. ${ }^{5,6,13-15}$ Our study demonstrated that most of the lesions occurred in Caucasian patients, which can be easily explained, as Caucasians correspond to $85.7 \%$ of the entire population in the Santa Catarina State according to data from the Instituto Brasileiro de Geografia e Estatística - IBGE. ${ }^{16}$

KCOT was the most frequent lesion observed in our study, comprising $51 \%$ of all lesions. Recently, KCOT has been reclassified by the WHO as a cystic lesion becoming a benign tumor. ${ }^{17} \mathrm{With}$ this reclassification KCOT became the most frequent odontogenic tumor; however, it is still difficult to find a series of studies including this lesion as an OT. ${ }^{1}$ The frequency of KCOTs in our study was $51 \%$ of all diagnosed cases, which was higher than the $28 \%$ to $36 \%$ frequency found in other studies. ${ }^{13,18-20} \mathrm{We}$ verified that the mean age of KCOT cases was 35 years, and that the posterior mandible was the most affected site. Data found in our study corroborate the data found in other studies, ${ }^{13,18}$ and we found a greater prevalence for the male gender, in agreement with the results reported by Jing et al. ${ }^{19}$ and González-Alva et al. ${ }^{21}$ The association of KCOT with NBCCS was seen in $40 \%$ of the cases, which is very different from what was reported by GonzálezAlva et al., ${ }^{21}$ who only found an association of $6 \%$. The same study reported data on the characteristics of the cases associated with NBCCS, reporting a greater prevalence in female patients $(63.6 \%)$, which was different from the observations of the present study, wherein we found a higher prevalence in male patients (57\% of cases associated with NBCCS). In our study, the age of NBCCS patients was between 5 , and 56 years, with a mean of 28 years, which differed from the findings presented by González-Alva et al., ${ }^{21}$ who presented cases whose age varied from 8 to 43 years with a mean of 19.5 years. Those authors also reported recurrence in only three cases, whereas it was observed in seven cases in our study.

Ameloblastoma is considered one of the most common lesions among OTs, and its incidence varies from $18 \%$ to $45 \% .{ }^{23}$ In our study, the incidence of ameloblastoma was $23 \%$ in all diagnosed cases, and these data are similar to findings from other studies. ${ }^{71,18,20}$ No gender-related preponderance was noted in our study, which was different from other studies in which the incidence in the female gender was higher. ${ }^{5,9,13,23,24}$ The most frequent clinical presentation was of the solid ameloblastoma $(61 \%)$ and, histologically, of the follicular variant $(33 \%)$. This is very similar to what was observed in the studies conducted by Ledesma-Montes et al., ${ }^{7}$ Osterne et al., ${ }^{13}$ Saghravanian et al..$^{15}$ and Santos et al. ${ }^{5}$ However, Fregnani et al. ${ }^{24}$ observed that the most frequent histological variant was the plexiform, which was observed in $53 \%$ of the cases. In our study, the posterior mandibular area was the preferred location, which was consistent with other studies. $5,7,13,14,19,22-24$

Odontoma, also considered a frequent OT, was the third-most common lesion in our study. In some studies, it is shown to be the most frequent lesion, ${ }^{5,6,12,22}$ although our study is more consistent with those conducted by Avelar et al., ${ }^{18}$ Fernandes 
et al.,${ }^{23}$ Jing et al., ${ }^{19}$ Jones and Franklin, ${ }^{9}$ Olgac et al. ${ }^{14}$ Osterne et al., ${ }^{13}$ and Saghravanian et al. ${ }^{15}$ in presenting an incidence of approximately $17 \%$. Our study is in agreement with the data found in the literature that show a higher frequency in female patients. ${ }^{5,13,15,22}$ In the present study, the mean age was 23 years, a result that is also similar to those found in the literature. ${ }^{5,15,19,23}$ The preferential location for these lesions was the posterior mandibular area, which corroborated the findings of Jing et al. ${ }^{19}$ and Saghravanian et al. ${ }^{15}$

Other lesions had a lower incidence, such as myxoma (3\%), CCOT (3\%), cementoblastoma (2\%), COF $(1 \%)$, and CEOT (1\%). This lower incidence can also be observed in other studies, such as those conducted by Avelar et al., ${ }^{18}$ Jing et al., ${ }^{19}$ and Santos et al. ${ }^{5}$ However, myxoma had a slightly higher incidence in some studies, such as in that conducted by Olgac et al. ${ }^{14}$ who observed an incidence of $16 \%$, being the third-most frequent lesion.

Very few studies have investigated OTs and, thus, a comparison between our results, and those published in the literature remains very difficult. Furthermore, the large ethnic diversity found worldwide, and even inside a single country with continental proportions, such as Brazil, creates substantial differences in the results. With the 2005 WHO

\section{References}

1. Barnes L, Everson JW, Reichart P, Sidransky D, editors. World Health Organization classification of tumours. Pathology and genetics of head and neck tumours. Lyon: IARC Press; 2005. $435 \mathrm{p}$.

2. Philipsen HP, Reichart PA. Classification of odontogenic tumours. A historical review. J Oral Pathol Med [Internet]. 2006 Oct [cited 2012 Oct 23];35(9):525-9. Available from: http://onlinelibrary.wiley.com/doi/10.1111/j.16000714.2006.00470.x/pdf.

3. Kramer IRH, Pindborg JJ, Torloni H. Histological typing of odontogenic tumours, jaw cysts, and allied lesions. Geneva, [London]: World Health Organization; 1971. 127 p.

4. Reichart PA, Philipsen HP, Sciubba JJ. The new classification of Head and Neck Tumours (WHO)--any changes?. Oral Oncol [Internet]. 2006 Sep [cited 2012 Oct 23];42(8):757-8. Available from: http://www.oraloncology.com/article/S13688375(05)00303-9/pdf. publication, ${ }^{1}$ it has become important to conduct new studies using this new classification of OTs so that a new panorama can be defined for the incidence of this group of lesions. In addition, multicentric studies that can establish the worldwide characteristics of OTs are also important.

\section{Conclusion}

In our study, the most frequent lesion was KCOT, comprising almost half of the diagnosed cases. This shows that with the modification of the classification of OTs, KCOT is possibly the most common lesion observed in diagnostic services worldwide. However, there is a lack of studies demonstrating these frequencies, including data even showing KCOT as an OT.

\section{Acknowledgements}

We thank the Pathological Anatomy Service and Clinical Data Records Service at the University Hospital at UFSC for their help in this study. This study was supported by Coordenação de Aperfeiçoamento de Pessoal de Nivel Superior (CAPES), which provided a doctoral fellowship, and the Conselho Nacional de Desenvolvimento Científico e Tecnológico $(\mathrm{CNPq})$, which provided an undergraduate research scholarship.

5. Santos JN, Pinto LP, Figueredo CR, Souza LB. Odontogenic tumors: analysis of 127 cases. Pesq Odontol Bras [Internet]. 2001 Oct-Dec [cited 2012 Oct 23];15(4):308-13. Available from: http://www.scielo.br/pdf/pob/v15n4/a07v15n4.pdf.

6. Sousa FB, Etges A, Corrêa L, Mesquita RA, Araújo NS. Pediatric oral lesions: a 15-year review from São Paulo, Brazil. J Clin Pediatr Dent. 2002 Summer;26(4):413-8.

7. Ledesma-Montes C, Mosqueda-Taylor A, Carlos-Bregni R, de Leon ER, Palma-Guzman JM, Perez-Valencia C, et al. Ameloblastomas: a regional Latin-American multicentric study. Oral Dis [Internet]. 2007 May [cited 2012 Oct 25];13(3):303-7. Available from: http://onlinelibrary.wiley.com/doi/10.1111/ j.1601-0825.2006.01284.x/pdf.

8. Ochsenius G, Ortega A, Godoy L, Penafiel C, Escobar E. Odontogenic tumors in Chile: a study of 362 cases. J Oral Pathol Med [Internet]. 2002 Aug [cited 2012 Oct 23];31(7):415-20. Available from: http://onlinelibrary.wiley. com/doi/10.1034/j.1600-0714.2002.00073.x/pdf. 
9. Jones AV, Franklin CD. An analysis of oral and maxillofacial pathology found in adults over a 30-year period. J Oral Pathol Med [Internet]. 2006 Aug [cited 2012 Oct 28];35(7):392-401. Available from: http://onlinelibrary.wiley.com/doi/10.1111/ j.1600-0714.2006.00451.x/pdf.

10. Ladeinde AL, Ajayi OF, Ogunlewe MO, Adeyemo WL, Arotiba GT, Bamgbose BO, et al. Odontogenic tumors: a review of 319 cases in a Nigerian teaching hospital. Oral Surg Oral Med Oral Pathol Oral Radiol Endod [Internet]. 2005 Feb [cited 2012 Oct 25];99(2):191-5. Available from: http://www. journals.elsevierhealth.com/periodicals/ymoe/article/S10792104(04)00628-6/pdf.

11. Odukoya O. Odontogenic tumors: analysis of 289 Nigerian cases. J Oral Pathol Med [Internet]. 1995 Nov [cited 2012 Oct 28];24(10):454-7. Available from: http://onlinelibrary.wiley. com/doi/10.1111/j.1600-0714.1995.tb01133.x/pdf.

12. Lima GS, Fontes ST, de Araújo LM, Etges A, Tarquinio SB, Gomes AP. A survey of oral and maxillofacial biopsies in children: a single-center retrospective study of 20 years in Pelotas-Brazil. J Appl Oral Sci [Internet]. 2008 Nov-Dez [cited 2012 Oct 25];16(6):397-402. Available from: http://www. scielo.br/pdf/jaos/v16n6/a08v16n6.pdf.

13. Osterne RL, Brito RG, Alves AP, Cavalcante RB, Sousa FB. Odontogenic tumors: a 5 -year retrospective study in a Brazilian population and analysis of 3406 cases reported in the literature. Oral Surg Oral Med Oral Pathol Oral Radiol Endod [Internet]. 2011 Apr [cited 2012 Oct 27];111(4):47481. Available from: http://www.journals.elsevierhealth.com/ periodicals/ymoe/article/S1079-2104(10)00828-0/pdf.

14. Olgac V, Koseoglu BG, Aksakalli N. Odontogenic tumours in Istanbul: 527 cases. Br J Oral Maxillofac Surg [Internet]. 2006 Oct [cited 2012 Oct 24];44(5):386-8. Available from: http://www.sciencedirect.com/science/article/pii/ S0266435605002196.

15. Saghravanian N, Jafarzadeh H, Bashardoost N, Pahlavan N, Shirinbak I. Odontogenic tumors in an Iranian population: a 30-year evaluation. J Oral Sci [Internet]. 2010 Sep [cited 2012 Oct 27];52(3):391-6. Available from: https://www.jstage.jst. go.jp/article/josnusd/52/3/52_3_391/_pdf.

16. Brasil. Instituto Brasileiro de Geografia e Estatística. Rio de Janeiro: IBGE; 2010. 317 p.

17. Philipsen HP. Keratocystic odontogenic tumour. In: Barnes L, Everson, JW, Reichart, P, Sidransky, D, editors. World Health Organization classification of tumours. Pathology and genetics of head and neck tumours. Lyon: IARC Press; 2005. p 306-7.

18. Avelar RL, Antunes AA, Santos TS, Andrade ES, Dourado E. Odontogenic tumors: clinical and pathology study of 238 cases. Braz J Otorhinolaryngol [Internet]. 2008 Sep-Oct [cited 2012 Oct 20];74(5):668-73. Available from: http://www.scielo.br/pdf/rboto/v74n5/en_v74n5a06.pdf.

19. Jing W, Xuan M, Lin Y, Wu L, Liu L, Zheng X, et al. Odontogenic tumours: a retrospective study of 1642 cases in a Chinese population. Int J Oral Maxillofac Surg [Internet]. 2007 Jan [cited 2012 Oct 29];36(1):20-5. Available from: http://download.journals.elsevierhealth.com/pdfs/journals/0901-5027/ PIIS0901502706004577.pdf.

20. da-Costa DO, Maurício AS, de-Faria PA, da-Silva LE, Mosqueda-Taylor A, Lourenço SD. Odontogenic tumors: a retrospective study of four Brazilian diagnostic pathology centers. Med Oral Patol Oral Cir Bucal [Internet]. 2012 May [cited 2013 Jan 26];17(3):e389-94. Available from: http:// www.ncbi.nlm.nih.gov/pmc/articles/PMC3476089/pdf/medoral-17-e389.pdf.

21. González-Alva P, Tanaka A, Oku Y, Yoshizawa D, Itoh S, Sakashita H, et al. Keratocystic odontogenic tumor: a retrospective study of 183 cases. J Oral Sci [Internet]. 2008 Jun [cited 2012 Oct 20];50(2):205-12. Available from: https:// www.jstage.jst.go.jp/article/josnusd/50/2/50_2_205/_pdf.

22. Guerrisi M, Piloni MJ, Keszler A. Odontogenic tumors in children and adolescents. A 15 -year retrospective study in Argentina. Med Oral Patol Oral Cir Bucal [Internet]. 2007 May [cited 2012 Oct 29];12(3):E180-5. Available from: http:// scielo.isciii.es/pdf/medicorpa/v12n3/01.pdf.

23. Fernandes AM, Duarte ECB, Pimenta F, Souza LN, Santos VR, Mesquita RA, et al. Odontogenic tumors: a study of 340 cases in a Brazilian population. J Oral Pathol Med [Internet]. 2005 Nov [cited 2012 Oct 26];34(10):583-7. Available from: http://onlinelibrary.wiley.com/doi/10.1111/j.16000714.2005.00357.x/pdf.

24. Fregnani ER, Perez DEC, Almeida OP, Kowalski LP, Soares FA, Alves FA. Clinicopathological study and treatment outcomes of 121 cases of ameloblastomas. Int J Oral Maxillofac Surg [Internet]. 2010 Feb [cited 2012 Oct 24];39(2):145-9. Available from: http://www.ijoms.com/article/S09015027(09)01188-6/pdf. 